\title{
Technological Innovation and Management Strategies for Higher Education in Africa: Harmonizing Reality and Idealism
}

\author{
Philip M. Uys, Paul Nleya and G.B. Molelu, Botswana
}

\begin{abstract}
This paper analyses and suggests possible technological innovation strategies in higher educational institutions in Africa. The paper describes management issues in the implementation of eLearning with particular reference to its usage in higher education abroad and in Africa, and also suggests appropriate approaches for technological innovation of higher education in Africa. The major findings of the paper, which are based on three case studies, suggest that eLearning needs to be implemented within a strategically developed framework based on a clear and unified vision and a central educational rationale. The findings further highlight the importance of using a combination of strategies - top-down, bottom-up and inside-out - during the diffusion process to attain coherence, collegiality and ownership. The process of technological transformation is not a smooth translation process but one of dislocations, dilemmas and uncertainties and it is an art to effect change and sustainable technological transformation since people are central to this transformation process.
\end{abstract}

L'innovation technologique et les stratégies de management pour l'enseignement supérieur en Afrique :

L'Harmonisation du réalisme et du l'idéalisme

Cet article analyse et suggère des stratégies d'innovation dans des établissements d'enseignement supérieur en Afrique. Il décrit les problèmes de management qui pose l'introduction du e-Learning avec une référence particulière pour son usage dans l'enseignement supérieur à l'étranger et en Afrique et suggère les approches appropriées pour l'innovation technologique dans l'enseignement supérieur en Afrique. Les résultats principaux exposés dans cet article qui sont fondés sur trois études de cas suggèrent que le e-Learning doit être introduit dans un cadre stratégique fondé sur une vision clairement unifiée et une rationalisation centrale de l'éducation. De plus ces résultats mettent en évidence l'importance de l'utilisation combinée de plusieurs stratégies : stratégies autant en bas, de bas en haut, d'intérieur et d'extérieur pendant le processus de diffusion afin d'aboutir à la cohérence, la collégialité et la possession. Le processus de transformation technologique n'est pas un processus de translation sans à compris mais un de dislocation, de dilemmes, d'incertitudes et c'est un art de procéder au changement et à une transformation technologique soutenue puisque les hommes sont au cœur de ce processus de transformation.

\section{Technologische Innovations- und Umsetzungsstrategien für höhere Bildung in Afrika: Realität und Idealismus} aufeinander abstimmen

Dieser Beitrag analysiert technologische Innovationstrategien und stellt Vorschläge für deren Einführung in höhereren Bildungsinstitutionen in Afrika zur Diskussion. Das Papier beschreibt Managementangelegenheiten bei der Umsetzung von eLearning unter besonderer Berücksichtigung seiner Anwendung in der höheren Bildung im Ausland und in Afrika und schlägt auch entsprechende Ansätze für die technologische Innovation im Bereich der höheren Bildung in Afrika vor. Das wesentliche Ergebmiss dieser Arbeit, die auf drei Fallstudien beruht, ist, dass eLearning innerhalb eines strategisch entwickelten Rahmens, basierend auf einer klaren und einheitlichen Sichtweise und einer zentralen bildungslogischen Grundlage eingeführt werden muß. Die Befunde heben weiter die Wichtigkeit hervor, eine Kombination von Strategien zu verwenden: Top-Down, Bottom-Up und Inside-Out Strategien während des Ausbreitungsprozesses, um Kohärenz, Kollegialität und Eigentumsrechte zu erlangen. Der Prozeß technologischer Transformation ist nicht etwa eine sanfte Überleitung, sondern von Verfremdung, Dilemmata und Unsicherheit begleitet. Es ist eine Kunst, Änderung und nachhaltige technologische Transformation zu bewirken, da ja die Menschen das zentrale Element dieses Transformationsprozesses sind.

Education Media International

ISSN 0952-3987 print/ISSN 1469-5790 online (C) 2004 International Council for Educational Media

http://www.tandf.co.uk/journals

DOI: $10.1080 / 0952398032000105120$ 


\section{Introduction}

The Information Age demands transformational initiatives. The pursuit of technological transformation in higher education has become widespread in Africa with the extensive pervasiveness of global networks like the Internet. The current focus of technological transformation in education seems to be centred on the use of the Internet and intranets, which is also referred to as eLearning. This paper, therefore, deals with instructional technology diffusion, with a focus on eLearning as a type and a central focal point of modern technological transformation in education, which has enormous potential to provide new connectivity and access for Africa internally and to the rest of the world.

The ideal is for Africa to grow its own best practice models for eLearning through creative grassroots initiatives, imaginative improvisation and contextualizing of best practice models from elsewhere. The realities of Africa need to be addressed if the ideals of using eLearning in teaching and learning are to be realized within the framework of the technological transformation of higher and tertiary education in Africa.

There are many aspects of the socio-economic and technological environment taken for granted in developed countries that need to be explicitly addressed during technological transformation in developing countries such as Botswana and the rest of Africa. These include, among other things, inadequate telecommunications infrastructure, lack of reliable power supply, the education sector competing for limited resources, a need to provide basic educational facilities, and reducing the student: teacher ratio to acceptable levels for effective learning. Many improvisations and special interventions are required and will need to be developed to address these issues.

Technological transformation in general and eLearning in particular has major systemic implications and needs to be carefully managed as Drucker (1998, p. 100) points out: 'as soon as a company takes the first tentative steps from data to information, its decision processes, management structure, and even the way it gets its work done begin to be transformed'. Attempts to introduce any significant reform will impact on all of its sub-systems. Bates (2000, p. 196) contends that 'using technology to extend the campus on a global basis will affect all aspects of a university or college, but particularly administrative systems'. Fullan (1991, p. 349) refers to the necessity of looking at innovations within the framework of institutional development. The systemic nature of transformation related to the wide and effective use of eLearning calls for a managed process to introduce this innovation in higher education in Africa.

Thomas et al. (1998) have argued for a transformation of practices (both teaching and administrative) in order to take advantage of technology so as to provide the needed functions, rather than superficial translation of existing practices. Bates (1999) argues that the introduction of eLearning will prompt 'a thorough re-examination of the core practices of an organization, whether advertising, or registration, or design and delivery of materials, or student support or assessment of students, in order to arrive at the most effective way of providing these services in a networked, multimedia environment'. Managing change in general and in higher education in particular is, however, problematic and it is therefore necessary, as Fullan (1991, p. 350) suggests, 'that we explicitly think and worry about the change process' in educational reform.

This paper has incorporated some of the key aspects of the doctorate research conducted by Dr Uys from 1995 to 2000 (Uys, 2000) and contextualizes it within higher education in Africa. It is primarily based on the action research findings from Massey University, New Zealand in implementing eLearning since September 1995, a five-month consultancy conducted in 2000 at the Cape Technikon, South Africa to initiate the wide implementation of eLearning, and on the University of Botswana eLearning (UBel) Initiative launched during 2001 to transform teaching and learning.

\section{Perspectives on the potential of eLearning to enhance higher education}

In Africa, there is a growing awareness and commitment to prepare students for effective participation in the emerging global knowledge economy. eLearning can be used in this regard to assist students to acquire skills and familiarity with the tools of the knowledge economy while studying. eLearning also has the potential to create continental and other international networks and links utilizing the connectivity of eLearning. In the context of a dynamic workforce through large staff turnover in Africa and the effects of HIV/AIDS, eLearning can also be used to create repositories of the intellectual and human capital in nations and in particular within higher educational institutions. 
eLearning is further seen as having the potential to increase the success rate of students through more formative feedback, repetition, access to wider materials and contact with other students and teachers who can provide additional support. eLearning can thus increase the support and communication between teachers and learners both locally and abroad. At the University of Botswana, eLearning is targeted towards the facilitation of more student-oriented, active, open and life-long learning approaches based on constructivism as articulated its vision and mission statements.

eLearning can also provide new levels of flexibility in learning and teaching with students studying at their own pace, place, time and preferred ways of navigation. eLearning can also be used to transcend geographical distances more effectively and it is also seen as a key strategy to counter the threat of national and international virtual institutes seizing traditional student markets. If managed well, eLearning can also increase access to education. In Africa in particular, the wide implementation of eLearning can be leveraged to create a demand for more sustainable and stable information and communication technologies (ICTs) such as wide area and local area computer networks, which is a pre-requisite for user-acceptance and wider support by stakeholders.

Technologically based education (eLearning) is further seen by some as a way to address the increase in the world demand for higher education. Daniel (1998, p. 12) states that 'one new university per week is required to keep pace with world population growth but the resources necessary are not available. Higher education must develop more cost-effective methods so that public resources can be focused on schools and youth training'. Bates (1999) concurs that by using technology for teaching at universities can serve the public more cost-effectively and in particular, can prepare students better for a technologically based society. In view of growing globalization and transnational exchanges in many fields, scholars like Marquardt, (1996, p. 3) and Evans and Nation (1993, p. 7) have indicated that in 'these circumstances politicians, policy-makers and citizens are making demands upon education systems to reform. Open learning and distance education are at the forefront of educational responses to the changes that are taking place locally, regionally, nationally and internationally'.

\section{Technological transformation and change management strategies in tertiary and higher education}

Some aspects of technological transformation that stood out at Massey University, Cape Technikon and in the last two years at the University of Botswana are discussed below within the framework of the literature on technological innovation in education and the management of the change process.

There is no neatly formulated theory of generic change. Cannon (1986) further points to the absence of a general theory of educational development and notes that educational developers therefore draw on theories from other disciplines to inform their educational practice. Higher educational institutes in general are very conservative and have been highly resistant to change and reform over the centuries (Evans and Franz, 1998; Richardson, 1979). Educational institutions in general, 'which exist to open minds and challenge established doctrine, are themselves extremely resistant to change' (Robbins and Barnwell, 1998). Higher education can be described as largely bureaucratic and 'bureaucracies by definition resist change' (Tapscott, 1996, p. 36).

The inherent aversion to change means that the concepts 'top-down' and 'strategic' need to be interchangeable for diffusion to be effective. Technological innovation has often been implemented as an isolated, bottom-up initiative of academic staff for efficiency purposes. In this scenario, the wider systems within higher education are often not considered and neither affected by the innovation. The management of an institute may thus feel justified in disregarding the innovation. Systems theory calls for an integrated approach to technological innovation: 'a system is a whole that cannot be taken apart without loss of its essential characteristics, and hence must be studied as a whole' (Ackhoff, 1972, p. 40).

At Massey University, the President served as the sponsor of the project but the project was not viewed as being of strategic importance, which led to limited diffusion. At both Massey University and Cape Technikon, however, the level of resources made available would not have been possible without senior management and middle management support. Furthermore, when typical political problems like irrational resistance to change were encountered, senior management was able to step in and direct matters.

At Cape Technikon, where the initiative was regarded as one of strategic importance, the top-down strategies included the creation of a widely owned strategic plan that included a clear and unified vision, having the Vice-Rector as sponsor and a task group with wide and senior representation as a sub-committee of Senate. 
Furthermore, a high level summit on eLearning was held, an extensive business plan was developed which was approved by the finance committee of Council, a presentation to Council was made and fortnightly input was provided at Rectorate meetings. This feedback created a strong top-down impetus and the creation of a reward structure by means of a central fund that encouraged participation confirmed the view of Berge and Schrum (1998, p. 35) that the key to success of campus initiatives in technology-enhanced learning and distance education is the support of campus leaders. This further correlates with Drucker's (1985) assertion that a successful innovation should aim at leadership from the beginning in order to be innovative enough and capable of establishing itself.

In educational reform in particular, the reward systems need to be tied to engagement with the processes that facilitate the desired reform. To enable the wide technological transformation of higher education, it needs to be stated as a strategic objective and direction, and the reward systems then need to be tied to its implementation (Munitz, 1997). The institute's reward systems should encourage academic staff and students to become and remain involved in eLearning if it desires to implement technology based education widely within the institute. Marquardt (1996, p. 97) contends that 'one of the most powerful management principles in the world is "That which get rewarded gets done".

A top-down innovation process is therefore important. Drucker (1985) points to the importance of a topdown process for a successful innovation aims at leadership. He believes that if it does not aim at leadership right from the outset, it is unlikely to be innovative enough, and therefore unlikely to be capable of establishing itself. This statement is made within the context of the business world, but with the increasing competitive nature of the educational milieu, this assertion is becoming more relevant for higher education.

Running regular workshops on relevant aspects for academic staff members was an effective bottom up strategy at both Massey University and Cape Technikon. At Cape Technikon the bottom up strategies further included using pilots to create successful role models in each faculty, aggressively extending the library holdings on eLearning, distributing possible research topics in eLearning to academic staff, holding an eLearning seminar week, running information sessions in each faculty and having a project team with wide representation. Furthermore, a centre for eLearning was established, an acronym and slogan competition for the project was held, regular news items appeared in the campus newspaper and in the Alumni and Student publications, a library exhibition on eLearning was organized, departmental meetings on eLearning were encouraged, eLearning was linked to other thrusts within the organization, and extensive individual conferencing occurred with interested academic staff members. These strategies led, for example, to an overwhelming response of 40 proposals for pilot projects.

An appropriate change model for technological infusion will also include inside-out strategies (Earl, 1989). The inside-out strategies attempt to understand perception, attitudes and behaviours of students, academic staff, project teams, processes and procedures in the University and addresses realities to support technological transformation. Middle management, that is heads of academic and administrative departments, can be key players in inside-out strategies. Middle management plays an important role in controlling resources - in some cases in a positive way, and in other cases in restricting support. The key inside-out strategy at Cape Technikon, however, was created when bottom-up and top-down strategies converged at faculty level in the workgroups that were established under the leadership of the deans in each faculty and chaired by an enthusiastic and capable academic. Each faculty workgroup consists of keen academic staff members and further with wide representation including administration, the information technology group and the Centre for eLearning.

A combination of top-down, bottom-up and inside-out processes seems possible in any higher institution that has ideals to be a true learning organization. Marquardt (1996, p. 218) contends in the context of the learning organization, 'it is possible for any member to be an awareness-enhancing agent or an advocate for new competence development. In this way, both top-down and bottom-up initiatives are made possible'. Gunn (1998, p. 142) asserts that:

An effective technology strategy works in both directions. From the top down, it is articulated through institutional objectives, sensitive to existing culture, constraints, strengths and weaknesses, and presented as a coherent, achievable set of goals with appropriate incentives and rewards. It must also move from the bottom-up where knowledge of teaching strategies, learning contexts and disciplinary expertise can be translated into action plans geared to achievement of institutional strategic objectives and so creating a sense of ownership at all levels of the institution.

Critical aspects of an integrated top-down, bottom-up and inside-out approach that emerged predominantly from these two cases are now discussed. 


\section{Pedagogical imperatives and ownership by academic staff}

It is vital that educators and a solid educational rationale drive the technological transformation of higher education so as to ensure ownership by academic staff as well as sound educational quality in eLearning (Caladine, 1993; Willmot and McLean, 1994). The structures supporting technology-based education have to ensure an educational focus and pre-eminence of educational principles rather than administrative desires or technical possibilities. Caladine (1993, p. 7), who reviewed the literature on nontraditional modes of delivery in higher education using state-of-the-art technologies, indicates that the extensive use of ICT in education 'poses previously unencountered problems in pedagogy and andragogy'. Bates (1992, p. 265) contends that 'technological decisions need to be preceded by policy and educational decisions'. This also highlights the importance of following bottom-up and more organic approaches during technological transformation in higher education.

Tillema (1995) considers engaging academics in the reform process as one of the two significant management issues to address in educational reform and in education in general. He asserts that reform has to be based on the development of 'learning communities'. That means that the actual process of reform must engage academics in local communities of discourse about their educational practices. Tillema further points out that historical studies, based largely on experience in schools, show that 'top down' attempts to achieve educational reform have failed, and suggests that they will be doomed to failure until they deal with the cultural and pedagogical traditions and beliefs underlying current practices and organizational arrangements. In technological transformation in higher education, it therefore seems necessary to address the concerns and perceptions of academic staff in the light of the need for changing their attitudes and to ensuring ownership by academic staff (Taylor et al., 1996; Evans and Franz, 1998).

Ownership of the technological transformation by academic staff is therefore critical as Bates (1984, p. 227) contends that 'the introduction of new technology in distance education requires major changes in professional roles'. Bates (1984) points to the need for specialized roles and the need for academics to gain the skills and knowledge for effective use of the new technologies, and the requirement for extensive training. These aspects would be amplified when managing the transformation of higher education through technology with its ICT base and range of technical options. Mason (1998, p. 157) asserts that the new technologies in global education point to 'a new role for the teacher, for the student and for course material. It centres on the construction of knowledge by the student ... a teacher as facilitator ... information is no longer something to organize, transmit and memorize, but something to work with, think with, discuss, negotiate and debate with partners'.

Ensuring ownership by academic staff was found to be essential in the diffusion of eLearning at Massey and Cape Technikon. Strategies such as one-to-one and small group discussions, demonstrations, academic involvement in decision-making wherever possible and explanation of the benefits of eLearning were used to ensure academic ownership. In order to ensure ownership by academic staff as well as sound educational quality in eLearning, it was important at both Massey University at Wellington and Cape Technikon for educators and educational principles to drive the technological transformation. This confirms similar views held by Szabo et al. (1997), Willmot and McLean (1994), Caladine (1993) and Tillema (1995).

The extensive interest in the workshops that the writer conducted regarding eLearning indicates that staff development can be used as an important strategy to advance the transformation of higher education through technology among academic staff.

The benefits and advantages of technology based education for the institute, teachers and students were consistently highlighted in these two cases in order to gain the positive interest of administrative managers and academic staff in the technological transformation of higher education. At the same time, specific issues relating to eLearning were identified and strategies to address these were developed as part of the strategic plan. The issues of intellectual property (Johnston and Challis, 1994) and copyright (McCullagh, 1995; Barnard, 1997) in particular are amplified in eLearning where copying and replicating materials are alarmingly easy. This issue is further complicated by the notion of instructional design through teams. A model of shared ownership can be explored where the institute retains the right to use the materials if members of the course development team should leave, and where staff have the right to use the materials developed by the team in their new environment. 


\section{Effecting change through development teams}

Academic staff may also act as the content experts in a multi-disciplinary course development team. (Holmberg, 1995, p. 135) contends that 'the various tasks are divided between a group of highly specialized team members, among them subject specialists, specialists in instructional design, media, technical production, etc., and editors'. Paquettee et al. (1996) describe the team roles in terms of 'five actor categories': learner, trainer, content-expert, manager and designer. Katz and Tushman (1997, p. 331) further highlighted the importance of the role of gatekeepers in the 'effective transfer and utilization of external technology and information'. Gatekeepers can be defined as key individual technologists who have a strong connection to both external sources of information and internal colleagues.

The specialized skills needed to develop technology based learning materials further point to the rationale for using development teams. Bates (1993, p. 232) asserts that producing good quality technology based learning materials 'will require people who can combine good pedagogic practice with an understanding of the strengths and weaknesses of different media and technologies'. Garrison (1989, p. 98, p. 117) points to 'course design teams ... as the accepted model in distance education' and that the British Open University uses course development teams extensively. Holmberg (1995, p. 98) confirms the predominant course-team model in distance education and that the main advantage of this model is that it operates to high professional standards. Garrison however also indicates that in distance education this model is not always considered '... feasible or appropriate for all distance education enterprises'. Holmberg (1995, p. 135) described the drawbacks of the team model as impeding personal approaches and also dealing with knowledge as a finished product instead of a complex process of 'knowledge under development'.

At both Massey University and Cape Technikon the use of a development team for eLearning was effective in operationalizing the strategic directives that included the development of eLearning materials. The following roles were used at both Massey University and Cape Technikon: a sponsor, project manager, content provider, creative director/graphic designer, computer specialist, instructional designer, editor and media developer. At Cape Technikon, the project team was extended to include a business manager, project secretary, IT representative, library representative and representative from administration and the six chairpersons of the Faculty eLearning Workgroups. The role of each team member at Cape Technikon to be a gatekeeper was emphasized.

During the development process at Cape Technikon, students were used to test and provide feedback on the materials. The student representative role however could be included on the team to be consistent with the central role that students play in eLearning. The student representative role can provide essential feedback during the development process and contribute to the internal quality assurance process.

\section{The ragged contour of the diffusion S-curve}

Innovation diffusion theory (Rogers, 1995) provides a general explanation for the manner in which new entities and ideas like eLearning, over time, disseminate through social systems - in this case, higher education. Rogers reviewed studies of diffusion of innovations from many technological contexts and forwarded a model for adoption of innovations describing key roles and behaviours in the adoption process. Innovation diffusion theory is essentially a bottom-up approach based on individual responses. Roger's diffusion of innovation curve can be used as a starting point to depict technological transformation in higher education. Initially, there is a take-off stage (that is introduction) during which an innovation is introduced in a social system. An entrepreneurial group called the innovators often then adopts it. During the next phase of maturation, the 'early adopters' - who are change agents or opinion leaders among the social system - will enter the process thereby legitimizing the innovation and opening the potential for adoption to all members of the system. The final saturation stage in an innovation's adoption is characterized by widespread adoption. The innovation saturates the social system and growth tapers off. This process can be plotted as an S-shaped growth curve.

Innovation in higher education - as with most innovations - however, takes place within the context of the organizational and management structures. According to Daft (1989, p. 274), 'organic organizations encourage a bottom-up innovation process', which is seen as typical for technological innovation. This position aligns itself with Roger's diffusion theory that also proposes a bottom-up approach when the innovation starts from outside management. Daft (1989, p. 274) however also indicates that administrative innovations follow a top-down direction of change within a mechanistic management structure. Daft (1989, p. 570) observes that 'the trend over the last thirty years has been toward more organic structures', which he 
partly attributes to 'greater environmental uncertainty and non-routine technologies'. In contrast, it seems that conventional management of higher education does not provide the required organic structures that foster innovation. Fullan (1991, p. 349) refers to this dilemma as the tension of 'combining individual and institutional development' and the necessity of having both in tandem for successful educational change.

The experience of pursuing technological transformation at both Massey University at Wellington and Cape Technikon does not confirm the smooth contours of Roger's diffusion of innovation curve. The various barriers that were encountered (both internally and externally), the uncontrollable events that negatively impacted on the implementation like key staff being allocated work with a higher priority, mistakes made and some fruitless experiments all point to a more ragged contour of the innovation curve.

Technological transformation at Massey University and Cape Technikon proved to be complex within its systemic dimensions and required a high level of determination by all involved and furthermore high standards of teamwork.

\section{A distributed implementation and support structure}

Bates (2000) suggests a distributed organizational structure for the support of eLearning. His model includes a fairly large professional centre while each faculty (or school) or large department will have a small flexible unit of technical support and generalist educational technology support. The centre will operate on a project management model with many of its staff seconded to work in the faculties on a continuing basis while the units will provide immediate support and find appropriate support from the centre for bigger projects. Szabo et al. (1997), who reported on technological transformation in higher education at the University of Alberta, Canada, suggest a similar approach:

There are two major intended goals of TIES [Training, Infrastructure and Empowerment System]. The first is that the chief academic officers identify a vision for alternative delivery systems of instruction for the university, publish that vision widely, and demonstrate their commitment to it in a clear and convincing fashion. Secondly, departments within the university create leadership task forces to interpret the vision for their unit and prepare colleagues to implement the shared vision.

At Cape Technikon the diffusion has been sustained through the use of a distributed implementation structure. A Centre for eLearning was established to provide central support and to coordinate the progress of the project. The task team on eLearning of Senate furthermore creates institute-wide policies. Linked to the central structure are workgroups within each faculty that includes a representative from the Centre for eLearning.

\section{The LASO (leadership, academic and student ownership and readiness) model for technological transformation in tertiary education}

The findings in these two cases suggests that Rogers' (1995) diffusion of innovation theory - when the innovation emerges from outside of senior management - needs to be augmented with a top-down component that includes both senior and middle management in order to accomplish effective diffusion of technology based education. This is a central finding by Dr Uys's doctorate research and the resultant LASO (Leadership, Academic \& Student Ownership and Readiness) Model for Technological Transformation in Tertiary Education that he developed (Uys, 2001), which was primarily based on these two cases.

The LASO model includes the necessary top-down, bottom-up and inside-out dimensions in the diffusion process. The LASO model (see figure 1) also attempts to address the wider context in which this transformation would take place within the 'Strategic Framework' namely the external technological and socio-economic environment.

The LASO Model emphasizes the importance of integrated top-down, bottom-up and inside-out processes. This model suggests that technological transformation occurs when leadership is integrated with academic and student ownership and readiness. Leadership is achieved through mechanisms such as defining a clear vision for the transformation, providing a reward structure for those engaging in the change process and the creation of a strategic framework to guide the transformation. Ownership and readiness for change by both students and academic staff can be achieved by using strategies such as pilot projects, extensive training, establishing workgroups in every faculty/school and using teams for courseware development. The curve of technological transformation is indicated in the LASO model as a ragged line to signify the complexities and dilemmas with which technological transformation is often associated. 


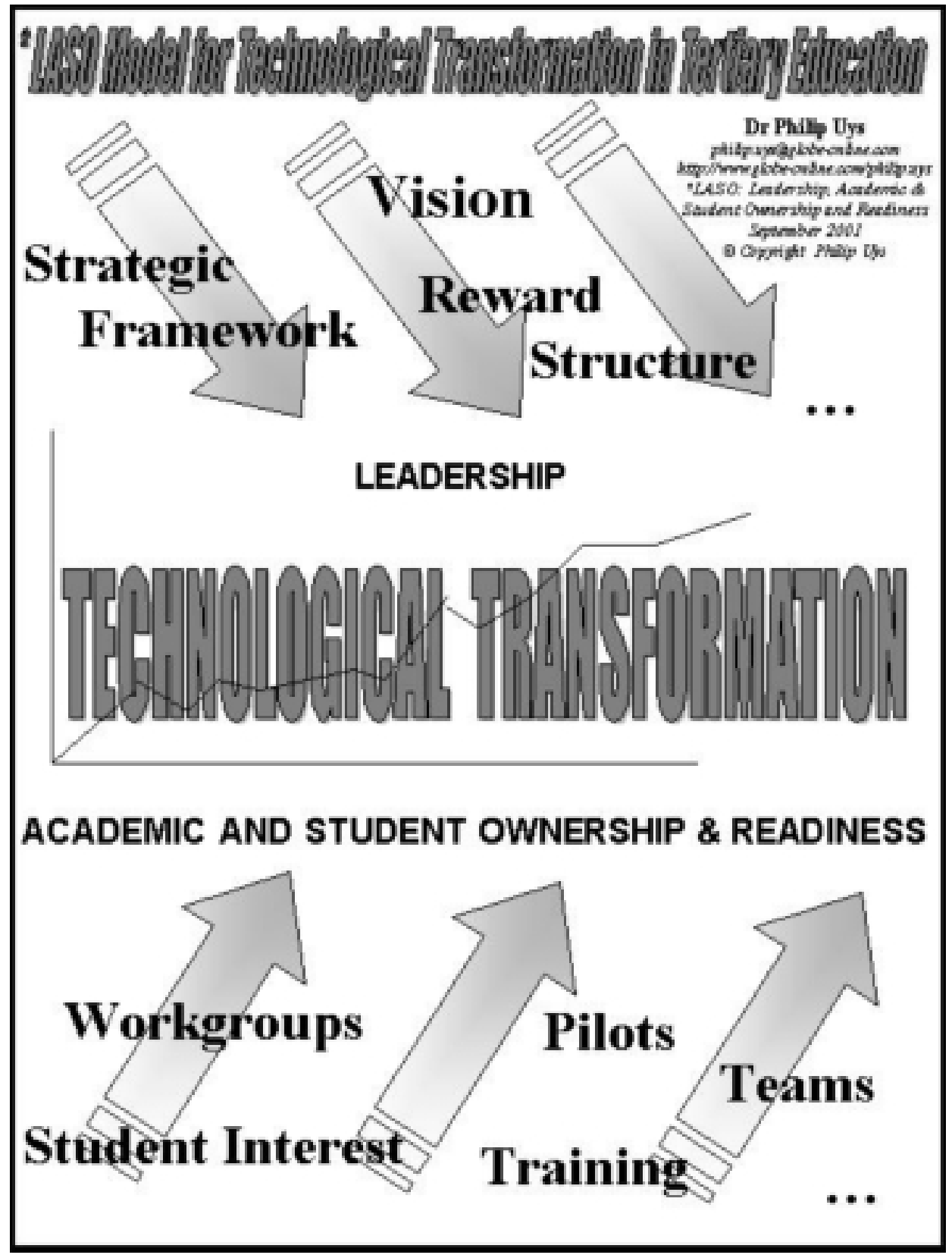

Figure 1 LASO (leadership, academic $\mathcal{E}$ student ownership $\mathcal{E}$ readiness) model for technological transformation in tertiary education.

The LASO model provided the conceptual framework for the strategic implementation of eLearning at the University of Botswana since February 2001. It was, however, the conviction of the authors that any change model needs to be contextualized within the complexities and culture of the environment in which such a model is to be implemented. The LASO Model could be considered a prototype that are being tested in the real world to yield the intended results, and the feedback from the field could be recycled to further develop 
the underpinning theoretical frameworks of the model. The University of Botswana served as some prime ground to validate the model in use.

The critical aspects of this model namely the pedagogical imperatives and ownership by academic staff, effecting change through development teams, the ragged contour of the diffusion S-curve and a distributed implementation and support structure were therefore analysed within the context of the University of Botswana. Some background, however, needs to be provided first on general aspects of technological transformation in Botswana and in other developing settings in Africa.

\section{Background to technological transformation in higher education in Botswana and Africa}

There are many aspects of the socio-economic and technological environment taken for granted in developed countries that need to be explicitly addressed in countries in Africa including Botswana. Some factors are clearly of a common nature like the need to address stakeholders' interest and government policy. These factors are critical in Africa where there is a high sense of community and where social factors play a key role in sanctioning strategic initiatives and even the allocation of funds. In this regard, Botswana has an international reputation for being relatively neutral in its policy-making. Government policy, however, does impact greatly on strategic initiatives such as the technological transformation of universities and often determines the parameters of such initiatives through laws, regulations, the allocation of funds and the support and guidance of its various ministries.

It has been noted that the lack of professionals trained to initiate and support new infusion of ICT has been the major factor militating against the effective adoption and utilization of ICT in developing countries in Africa and elsewhere. Educational institutions in Africa, especially at the tertiary level, play one of the key roles in providing the needed intellectual resources for their societies. Many of the organization, management and development issues as they pertain to ICT education and infusion, however, are not represented in the curricula of higher education institutions in developing countries. At the University of Botswana, it is the Department of Educational Technology (DET) in the Faculty of Education, which carries this task in relation to Educational Technology courses being offered to Education Students. The DET is currently developing academic programmes to be launched.

The development of professionals in the effective and appropriate use of educational technologies is carried out at the University of Botswana by the Educational Technology Unit (EduTech) in the Centre for Academic Development (CAD), supported by the Teaching and Learning Unit which focuses on the transformation to a student-oriented learning environment. EduTech has been charged with the responsibility of the technological transformation at the University of Botswana. A major initiative of this unit is the launching of a University-wide eLearning initiative (UBel) that has been phased in with consideration to the above constraints. A needs assessment is being implemented to identify the gaps by exploring and adapting the eLearning programme to the complex pedagogic and cultural environment in which staff work at the University of Botswana.

The Deputy Directorate of Affiliated Institutions is yet another component of CAD that is responsible for the accreditation of affiliated tertiary institutions countrywide. This deputy directorate acts as a critical channel and agent to diffuse eLearning into the 12 affiliated institutions of the University of Botswana.

Ojo and Awuah (1998) have alleged that several multi-faceted challenges exist that militate against the effective diffusion and adoption of ICT in developing countries. They have categorized these as being operational, contextual and strategic by nature. Jain (2001) has also alluded to the above categorization of operational, contextual and strategy constraints. The operational pertain to the resources needed before using ICT (i.e. human resources, political will, sufficient communication structure, finance, adequate implementation of ICT projects, etc.). Contextual constraints relate to issues such as model mismatch. For example, ICT facilities used to solve some problem in the developed world might not necessarily be compatible with the context in the developing world. The strategic constraints refer to notions such as national policies, mission statements and values. The two studies conducted in Botswana - Ojo and Awuah (1998) and Jain (2001) concluded that the above constraints need to be carefully considered in order to initiate effective adoption and utilization of ICT in developing countries. The authors have noted that these constraints were not peculiar to Botswana, but that they could be generalized to the different contexts in the developing countries in Africa and elsewhere. 
Gibson (1998) has also observed that 'the adoption of a novel technology requires new labour skills that are usually not found in Less Developed Countries (LDCs)'. This tends to confirm common perceptions that the developing countries encounter problems with ICT because of their local environment/traditional culture, affordability, improper/insufficient training and improper/insufficient infrastructure and educational curriculum.

An inadequate telecommunications infrastructure will hamper the strategic implementation of eLearning as it is based on ICT. Limited bandwidth due to either cost factors or the scarcity of modern equipment has a negative affect on the potential use of ICT and on user acceptance of the new technologies. The lack of reliable power supply in some African countries, as is the case in Botswana, further creates a necessity for special interventions to ensure that an adequate platform for eLearning is in place. The privatization of telecommunication is an imperative especially in countries like Botswana where a monopoly contributes to the high cost of Internet bandwidth and access and hinders the necessary growth in the provision of quality services in the telecommunication industry.

In Botswana, the education sector competes for the limited resources with the other equally deserving sectors of the economy like health. The continued growth of eLearning may be considered in some circles as not topping the priority list of those in control of the national purse. Like in most African countries there is still a need to provide basic educational facilities in most parts of the country like building adequate class rooms in schools and also to reduce the student: teacher ratio which in 1993 was 1:45 in primary and 1:35 in secondary schools to acceptable levels for effective learning (Botswana Ministry of Education, 1993). These challenges are amplified in developing countries through the notion of 'massification of education' as governments demand, legislate and provide funding to ensure higher participation in all levels of education.

The University of Botswana has been fortunate in many respects regarding the application and implementation of educational technology into the curriculum and using such technology to expand access. The university has a very robust technology infrastructure. Every staff has a Pentium computer, printer or access to a printer, access to the Internet and e-mail with minimal power failures and network shutdowns. A new library extension has recently been completed and 800 new student workstations will be soon be available in order to create a technology rich learning environment.

\section{Pedagogical imperatives and ownership by academic staff in UBel}

The first critical assertion of the LASO model is that educators and a solid educational rationale should drive the technological transformation of higher education so as to ensure ownership by academic staff as well as sound educational quality in eLearning. UBel is driven by an educational philosophy due to its base within the Centre for Academic Development through the leadership of EduTech. This philosophy is evident in the definition of eLearning at the University as 'the appropriate organization of information and communication technologies for advancing student-oriented, active, open, collaborative and life-long teaching-learning processes'. The emphasis is, therefore, on a blended approach in which various modes, methods and media can be integrated and organized for appropriate learning.

The rationale for using eLearning at the University include to increase the quality of learning and the success rate of students, to create and support new research opportunities and to alleviate increasing administrative and teaching pressures on academic staff, to support academic freedom and freedom of speech through free information flows and to make teaching more exciting.

Academics are deeply involved in the reform process through the UBel Committee. Each school/faculty is represented by two academic staff members who lead the eLearning programme within their school/faculty. Academic staff through the UBel Committee were central to the selection of the online Learning Management System, conducting a University-wide needs analysis and the design of an eLearning pilot programme.

Ownership of the technological transformation by academics is further enhanced through their involvement in extensive training. EduTech has run more than 50 eLearning workshops since February 2001, and these were attended by more than $30 \%$ of all academic staff at the University. Ensuring ownership by academic staff was further encouraged through presentations at faculty executive meetings and faculty board meetings. The benefits and advantages of technology based education for the University, teachers and students are consistently highlighted in these presentations in order to gain the positive interest of administrative managers and academic staff in the technological transformation of higher education. 


\section{Effecting change through development teams in UBel}

The LASO model also asserts that change can be realized through courseware development through development teams. The University of Botswana is indeed busy with the appointment of a full development team. An instructional designer has already joined the University while an online media developer and graphic designer will join the University by the end of 2002. The instructional designer has worked closely with academic staff to guide them towards a more student-oriented, problem-based approach in online learning. This process is critical when the transformation process is geared towards educational goals, as is the case at the University.

The UBel Committee is also involved in the development of development policies and procedures. This committee includes critical gatekeepers such as the Deputy Director of the Programme Review unit in the Centre for Academic Development, the Deputy Director of the Teaching and Learning unit in the Centre for Academic Development and the Dean of the School of Graduate Studies who transfer and utilize external technology and information through their strong connection to both external sources of information and internal colleagues.

It is envisaged that University students will be represented on the development teams to evaluate and test the course materials. A member of the Student Representative Council (SRC) serves on the UBel Team. Participation of students so far however, has been problematic due to difficulties in communication, commitment and different priorities due to their academic responsibilities.

\section{The ragged contour of the diffusion S-curve in UBel}

The ragged contour of technological transformation as depicted in the LASO model has also been confirmed at the University of Botswana in contrast to the smooth contours of Roger's diffusion of innovation curve. Significant complexities and dilemmas evident within the transformation process at the University include relationships among UBel committee members, access of students to computers, stability of information and communication systems, student participation, resistance to change among academic staff and extensive time delays due to administrative processes and procedures.

\section{A distributed implementation and support structure in UBel}

At the University of Botswana, a satellite communication structure for eLearning is being implemented. The UBel Committee has representatives from every school/faculty as the starting point for such a distributed approach. Every school/faculty further has an eTeam who are led by the school /faculty representative on the UBel Committee.

At the University, a similar distributed support structure is also being planned as second layer of a comprehensive distributed support and communication system. EduTech currently provides central support and coordinates UBel through the UBel Committee. A satellite support centre linked to EduTech is being planned for each school/faculty.

\section{Conclusion}

The LASO Model for technological transformation in tertiary education that has emerged from the New Zealand and South African cases has been largely validated within the context of the University of Botswana. Technological transformation is still embryonic at the University of Botswana but is clearly gaining momentum through the integrated top-down, bottom-up and inside-out strategies being implemented within the framework provided through the LASO model. The culture and complexities of the University of Botswana also affects the political dimensions of this process and further impacts on expectations and targets.

The analysis of these three cases indicates that technological innovations like eLearning need to be implemented within a strategically developed framework based on a clear and shared vision and a central educational rationale. The several multi-faceted challenges that exist and militate against the effective diffusion and adoption of ICT in developing countries should be taken into consideration. These have been categorized as being operational, contextual and strategic by nature and have been dealt with in the paper with the intention of adapting and diffusing ICT innovations to their optimum potential at the tertiary level in Africa. 
The management of technological innovation or infusion therefore needs to utilize a combination of strategies; top-down, bottom-up and inside-out strategies during the diffusion process to attain coherence, collegiality and ownership. The process of technological transformation is complex with many dislocations, dilemmas and uncertainties. It is an art to effect change and sustainable technological transformation since people are central to this transformation process. The LASO Model (Uys, 2001) can act as a guiding heuristic or framework for the technological transformation of higher institutions in Africa.

The challenge to institutions in Africa, despite these several constraints identified, is for the leadership at the tertiary level to continue to develop strategic models that are compatible with their context and visions, and implementing these diligently. There is every opportunity for institutions to create educational environments that promote self-directed learners who are life long learners in a global village. There is research evidence that support that a mixed mode or blended approach in eLearning provides best results. Croft (1995) has cautioned that 'just because we put a PC on everyone's desk, we should not automatically assume we have solved the challenge of global communication'. Developing countries in Africa would also benefit from collective experience and the sharing of scarce resources in diffusion and adoption of ICT in education and training.

Naidoo and Schutte (1999, p. 90) point to the need for leadership in the process of technological transformation in Africa: 'If African countries cannot take advantage of the information revolution and surf this great wave of technological change, they may be crushed by it . . Catching this wave will require visionary leadership in Africa'. The implications are that institutions and individuals in Africa and internationally who are committed to the appropriate use of eLearning need to demonstrate new levels of leadership while at the same time being life-long learners themselves.

'In a time of drastic change it is the learners who survive;

the 'learned' find themselves fully equipped

to live in a world that no longer exists'

(Eric Hoffer)

\section{References}

Ackhoff, R (1972) A note on systems science. Interfaces, August 40, WP Press, Wellington.

Barnard, J (1997) The World Wide Web and higher education: the promise of virtual universities and online libraries, Educational Technology, May-June, 30-35.

Bates, AW (ed.) (1984) The role of technology in distance education, Croom Helm, London.

Bates, AW (1992) Technology for distance education, In Tait, A. (ed.) Key issues in open learning, Longman, Harlow, pp. 241-265.

Bates, AW (1993) Theory and practice in the use of technology in distance education. In Keegan, D (ed.) Theoretical Principles of Distance Education, Routledge, London, pp. 213-233.

Bates, AW (1999) Strategies for the Future. Available online: http://bates.cstudies.ubc.ca/strategies.html (accessed 23 November 2002).

Bates, AW (2000) Managing technology change. Strategies for college and university leaders, Jossey-Bass, San Francisco.

Berge, ZL and Schrum, L (1998) Strategic planning linked with program implementation for distance education, CAUSE/EFFECT, 21, 3, 31-38.

Botswana Ministry of Education (1993) Revised National Education Policy, Government of Botswana.

Caladine, R (1993) Overseas Experience in Non-Traditional Modes of Delivery in Higher Education Using State-of-theArt Technologies: A Literature Review, Australian Government Printing Service, Canberra.

Cannon, RA (1986) Theoretical perspectives in changing tertiary education. In Jones, J and Horsburgh, M (eds) Research and development in higher education, HERDSA, Kensington, Australia.

Croft, B (1995) Technology and Global Communication. Published as an Opening Window to the World. Available online: http://www.inforamp.net/ bcroft/brian13a.html (accessed 1 November 2001).

Daft, RL (1989) Organization Theory and Design, 3rd edn, West Publishing, St. Paul, MN.

Daniel, JS (1998) Mega-universities and knowledge media. Technology strategies for higher education, Kogan Page, London.

Drucker, PF (1985) Innovation and Entrepreneurship, Heinemann, London.

Drucker, PF (1998) Peter Drucker on the profession of management, Harvard Business School Publishing, Boston, MA.

Earl, M (1989) Multiple methodology. Management strategies for information technology, Prentice Hall, Cambridge. 
Evans, FJ and Franz, JB (1998) Managing change in the global university. Proceedings of the Towards the Global University: Strategies for the Third Millennium Conference, April, University of Central Lancashire.

Evans, T and Nation, D (1993) Reforming Open and Distance Education. Critical Reflections, Kogan Page, London.

Fullan, MG (1991) The New Meaning of Educational Change, 2nd edn, Cassel Education Ltd, London.

Garrison, DR (1989) Understanding distance education. A framework for the future, Routledge, London and New York.

Gibson, R (1998) Informatics diffusion in South American developing economics, Journal of Global Information Management, 6, 2, 36.

Goldenfarb, M (1995) Critical Success Factors in Diffusing a Campus Wide Information System. Paper presented at AusWeb95 - The First Australian World Wide Web Conference. Available online: http: //www.scu.edu.au/sponsored/ausweb/ausweb95/papers/education4/goldenfarb/ (accessed 20 June 1998).

Gunn, C (1998) Virtual technologies in higher education: vision or reality? In Peters, M and Roberts, P (eds) Virtual Technologies and Tertiary Education, Routledge, London, pp. 134-145.

Holmberg, B (1995) Theory and Practice of Distance Education, 2nd edn, Routledge, London.

Jain, P (2001) An Analysis of Information Technology (IT) Diffusion in Botswana: A Study of Gaborone. Independent self-sponsored research project, Botswana College of Agriculture.

Johnston, R and Challis, K (1994) The learning relationship: a study of staff development and satisfaction in relation to distance learning teaching, International Journal of University Adult Education, 33, 1, 62-76.

Katz, R and Tushman, ML (1997) A study of the influence of technical gatekeeping on project performance and career outcomes in an R\&D facility. In Katz, R (ed.) The Human Side of Managing Technological Innovation: A Collection of Readings, Oxford University Press, New York, pp. 331-346.

Katz, R (ed.) (1997) The Human Side Of Managing Technological Innovation: A Collection Of Readings, Oxford University Press, New York.

Marquard, MJ (1996) Building the Learning Organization - a Systems Approach to Quantum Improvement and Global Success, McGraw-Hill, New York.

Mason, R (1998) Globalising Education. Trends and Applications, Routledge, London.

McCullagh, A (1995) What are the risks? (1). Paper presented at New Media and On-line Commerce conference, Brisbane, September.

Munitz, B (1997) The New Educational Paradigm. Keynote at the 18th World International Council for Distance Education Conference, ICDE, Pennsylvania.

Naidoo, V and Schutte, C (1999) Virtual institutions on the African Continent. In Farrell, GM (ed.) The development of virtual education: a global perspective, The Commonwealth of Learning, Vancouver, pp. 89-124. Available online: http://www.col.org/virtualed/index.htm (accessed 23 November 2002).

Ojo, S and Awuah (1998) Building resource capacity for IT education and training in schools - the case of Botswana. In Marshall, G and Ruohonen, M (eds) Capacity Building for IT in Education in Developing Countries, Chapman \& Hall, London.

Paquettee, G, Ricciardi-Rigault, C, Paquin, C, Liegeois, S and Bleicher, E (1996) Developing the virtual class environment. Proceedings of the ED-MEDIA 96-World Conference on Educational Multimedia, Hypermedia \& Telecommunications, June, AACE, Boston, MA.

Richardson, JM, Jr (1979) Information technology serving society: past, present and future. In Chartrand, RL and Morentz, JW (eds) Information technology serving society, Pergamon Press, Elmsford, NY, pp. 119-124.

Robbins, SP and Barnwell, N (1998) Organisational Theory: Concepts and Cases, 3rd edn, Prentice Hall, Sydney.

Rogers, E (1995) Diffusion of Innovations, 4th edn, Free Press, New York.

Szabo, M, Anderson, T and Fuchs, A (1997) A change system: the training, infrastructure and empowerment system: (TIES). Available online: http://www.quasar.ualberta.ca/edmedia/TIES/TIES_Report.html (accessed 10 July 1999).

Tapscott, D (1996) The Digital Economy: Promise and Peril in the Age of Networked Intelligence, McGraw-Hill, New York.

Taylor, P, Lopez, L and Quadrelli, C (1996) Flexibility, Technology and Academics' Practices: Tantalising Tales and Muddy Maps, Evaluations and Investigations Programme, Department of Employment, Education, Training and Youth Affairs, Canberra. Available online: http://www.anu.edu.au/uniserve/eip/muddy/ muddy.html (accessed 20 June 1998).

Thomas, O, Carswell, L, Price, B and Petre, M (1998) A holistic approach to supporting distance learning using the Internet: transformation, not translation, British Journal of Educational Technology, 29, 2, 149-161. 
Tillema, HH (1995) Changing the professional knowledge and beliefs of teachers: a training study, Learning and Instruction, 5, 291-318.

Uys, PM (2000) Towards the virtual class: key management issues in tertiary education. Unpublished PhD thesis, Victoria University of Wellington, New Zealand.

Uys, PM (2001) LASO (Leadership, Academic E Student Ownership and Readiness) Model for Technological Transformation in Tertiary Education. Available online: http://www.globe-online.com/philip.uys/LASOmodel.htm (accessed 23 November 2002).

Willmot, M and McLean, M (1994) Evaluating flexible learning: a case study, Journal for Higher Education, 18, 3, 99-108.

\section{Biographical notes}

Dr Philip M. Uys is Deputy Director of the Centre for Academic Development (Educational Technology) in Botswana. He has extensive experience in the strategic implementation and general and project management of eLearning - both in developing and developed environments. He is a former senior lecturer (educational technology and educational leadership) of Massey University in New Zealand.

Dr Paul Nleya is a Senior Lecturer and Head of the Department of Educational Technology in the Faculty of Education, and Mr G.B. Molelu is Manager of Educational Technology in the Centre for Academic Development. All are at the University of Botswana.

\section{Address for correspondence}

Dr Philip M. Uys, Deputy Director of Educational Technology, Centre for Academic Development, University of Botswana, Private Bag, UB 0022, Gaborone, Botswana; e-mail: uyspm@mopipi.ub.bw or philip.uys@globeonline.com 